\title{
Drugs and appetite
}

\section{By G. L. S. Pawan, Metabolic Division, The Middlesex Hospital Medical School, London $W \mathrm{x} P{ }_{7} P N$}

Natural feeding behaviour in animals is genetically determined and is characteristic of the species. In the normal adult animal with readily available food supplies, the balance between energy intake from food and over-all energy output from the body is regulated with remarkable accuracy over long periods of time. This homeostatic regulation is controlled by the central nervous system, which monitors the feed-back of information on energy utilization for work, body temperature (in homeotherms) and body energy stores, and adjusts food intake to meet these energy requirements. It has been experimentally demonstrated in many animal species that the co-ordinated activity of the lateral ('feeding centre') and ventro-medial ('satiety centre') areas of the hypothalamus, together with the limbic system, reticular formation and other areas of the brain, integrates the incoming information and, via the sensations of hunger, appetite and satiety, initiates the drive to eat and controls feeding behaviour and food intake (Mayer, 1953, 1955 $a, b$; Anand, 1961; Morgane \& Jacobs, 1969; Baile, 1971; Bell, I97I; Baile \& Forbes, 1974). Various theories have been proposed to explain the nature and mode of action of the signals which affect the central nervous regulation of food intake (Table I). They all have some experimental support, but none alone explains all the facts. There is no doubt, however, that the sensations of hunger, appetite and satiety are involved in the control of food intake, and agents which affect these sensations are therefore of considerable interest to nutritionists.

Table I. Theories on the control of food intake: drugs may affect 'appetite' by modifying the nature and intensity of the 'signals'

\begin{tabular}{|c|c|}
\hline Theory & $\begin{array}{l}\text { Origin of signals } \\
\text { to the central nervous system }\end{array}$ \\
\hline \multirow[t]{2}{*}{ Gastrointestinal } & Visual, olfactory, oral, pharyngeal \\
\hline & $\begin{array}{l}\text { Gastric distention, contraction } \\
\text { Osmolarity }\end{array}$ \\
\hline Thermostatic & Peripheral and central heat monitors \\
\hline Glucostatic & Specific receptors for glucose \\
\hline Lipostatic & $\begin{array}{l}\text { Innervation of fat tissue } \\
\text { Concentration of circulating metabolites } \\
\qquad \begin{array}{l}\text { Progesterone? } \\
\text { Prostaglandin? }\end{array}\end{array}$ \\
\hline Amino acid pattern & Extracellular amino acids \\
\hline $\begin{array}{l}\text { Hypothalamic } \alpha \text { - } \\
\text { and } \beta \text {-adrenergic } \\
\text { receptors }\end{array}$ & Resultant effect of agonists and antagonists \\
\hline
\end{tabular}

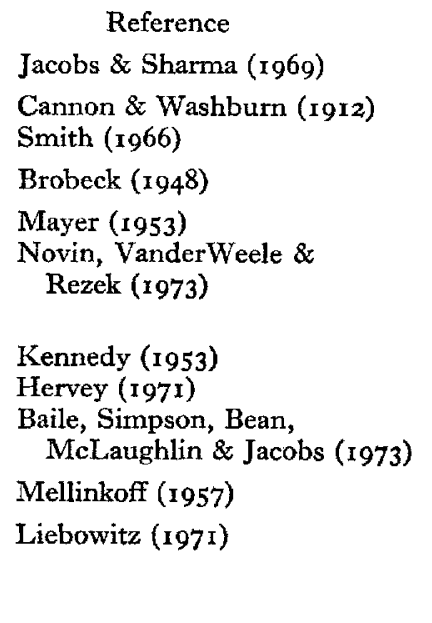

$33(3) 4$ 
The importance of obesity and the growing awareness of the association between over-weight and morbidity and mortality from a range of diseases in man, together with the nutritional and economic aspects of the relationship between foodstuffs, feeding behaviour and carcass composition in farm animals, have stimulated research on drugs which modify appetite and food intake. This paper will deal with drugs and appetite in man. Ruminant nutritionists are recommended to read the excellent review of the subject by Baile \& Forbes (1974).

There is a paucity of precise scientific studies on the effect of drugs on appetite in man. Emotional, psychological, pathological, cultural, religious, social and economic factors as well as the appearance, taste, palatability, odour and texture of foods exert important effects on appetite and food intake, and complicate the interpretation of experimental results (Silverstone, I973; Bruch, 1974). In laboratory animals, controlled studies on the effect of drugs on food intake and neurophysiological experiments on the central nervous system responses are of value, but extrapolation of these findings to man must, of necessity, be cautious. Double-blind studies, body-weight change and 'appetite rating' measurements are useful-but inevitably show considerable variations among different groups of subjects. Nevertheless, important information on the effect of certain drugs on appetite in man has been collected.

\section{Drugs which increase appetite}

Alcohol. A small amount of ethanol taken as an aperitif before a meal increases appetite by stimulating the sense of taste, increasing flow of saliva, gastric and pancreatic secretions, and, by inhibiting higher centres in the brain, produces relaxation and a feeling of well-being (Dreiling, Richardson \& Fradkin, 1952). Large amounts of alcohol, however, depress appetite, as frequently seen in alcoholics (Beazell \& Ivy, 1940).

Insulin. Increased appetite and food intake are produced in simple-stomached animals like the rat by glucopoenia of the glucoreceptors (Mayer, 1955 $a, b$; Anand, Chhina \& Singh, 1962). This is seen following the administration of insulin, protamine-zinc-insulin (Nahum \& Himwich, 1932; MacKay, Callaway \& Barnes, I940), and glucose analogues like 2-deoxy-D-glucose (Smith \& Epstein, I969; Novin, VanderWeele \& Rezek, 1973). Insulin-induced hypoglycaemia and 'hunger diabetes' in man are associated with increased appetite. In ruminants, however, insulin-induced hypoglycaemia may produce a reduction in food intake (Baile \& Forbes, 1974).

Steroids. Progesterone increases food intake in the rat (Hervey \& Hervey, 1964) possibly by decreasing the endogenous production of oestrogen (Hervey, 1971). The effect of oestrogens varies with animal species and other conditions. Oestrogen depresses food intake in the goat, apparently by a direct effect on the ventro-medial hypothalamus (Forbes \& Rook, 1970), and in the rat (Meites, 1949). Stilboestrol appears to increase food intake in ruminants (Braude, 1948; Dinusson, Andrews \& Beeson, 1950). In man, androgens and anabolic steroids like norethandrolone (Nilevar), methandienone (Dianabol), and nandrolone (Durabolin), appear to exert slight effects on appetite; and corticotrophin and some glucocorticoids, e.g. cortisone, 
may increase appetite in man (Goslings, Hymans, Van Limpt \& Van Gilse, 1950; Hench, Kendall, Slocumb \& Polley, I950), and in many other species like the mouse (Kekwick \& Pawan, 1965) and sheep (Spurlock \& Clegg, 1962; Bassett, 1963).

Other Hormones. In the rat, growth hormone has been reported to increase food intake (Kennedy \& Mitra, 1963). In man, its effect is equivocal. It is well known that thyroid hormones improve appetite and increase metabolic rate in hypothyroid subjects.

Sulphonylureas. These oral antidiabetic agents, particularly tolbutamide, chlorpropamide, tolazamide, glibenclamide, acetohexamide and the sulphonamide pyrimidine-glymidine, may increase appetite and weight gain, possibly via a stimulating effect on pancreatic insulin release.

Psychotropic drugs. In depressed subjects, an improvement in appetite is often seen following administration of antidepressants (Settel, 1958). Similarly, anxious and agitated persons frequently show increased appetite on treatment with tranquillizers, e.g. the phenothiazines like chlorpromazine (Largactil), and benzodiazepines like diazepam (Valium), chlordiazepoxide (Librium) and medazepam (Nobrium).

Antihistamines. Buclizine, an antihistamine with tranquillizing properties, has been used with some success, particularly in South America, to stimulate appetite and increase body-weight in children (Higa, Micelli \& Astolfi, I969). In mice, this drug produced a slight increase in food intake for a few days, but over a 4-week period this was not statistically significant (Pawan, unpublished results). Cyproheptadine (Periactin), an antihistamine serotonin-antagonist used in the treatment of pruritis, has been reported to cause an increase in appetite and in body-weight in some clinical conditions (Lavenstein, Dacaney, Lasagna \& Van Metre, 1962; Noble, 1969; Benady, r970; Sanzgiri, Mohamad \& Raja, 1970; Stiel, Liddle \& Lacy, 1970; Silbert, I971; Mainguet, 1972). The mode of action of this drug may be via a hypoglycaemic action (Drash, Elliott, Langs, Lavenstein \& Cooke, 1966) or a direct effect on the hypothalamus (Chakrabarty, Pillai, Anand \& Singh, 1967).

Other Drugs. Several other drugs have been reported to increase appetite and food intake, for example certain antibiotics, like chlortetracycline (Jukes \& Williams, 1953), the rauwolfia alkaloid reserpine (Hollister, r957), sodium salicylate (Becker, 1958), and in animals, drugs which damage the hypothalamus, like gold thioglucose (Mayer, I955a,b). Animal studies have also shown that in some species, drugs which affect the $\alpha$ - and $\beta$-adrenergic receptor cells in the hypothalamus may influence appetite (Liebowitz, 1970, 1971). Thus $\beta$-antagonists like DL-propranolol, when injected into the lateral hypothalamus, and $\alpha$-agonists like L-norepinephrine, injected into the ventro-medial hypothalamus, produce increased hunger (Baile \& Forbes, 1974).

At the present time, no really safe and effective drug is available for reliably increasing appetite to a significant degree in man.

\section{Drugs which reduce appetite}

Bulk Agents. These substances do have a slight effect on appetite and are sometimes used in man. Methyl-cellulose (Celevac, Cellucon) and guar gum (Decorpa) are 
examples. They take up fluid and swell in the stomach giving a feeling of fullness, which can reduce appetite (Anand \& Pillai, 1967). However, in treatment of obese subjects they have not been effective (Munro, r973).

Amphetamines and related compounds. These sympathomimetic amines are widely known to be effective anorectic agents. In the past a large number were used by clinicians to reduce appetite in over-weight patients, e.g. amphetamine (Benzedrine), dexamphetamine (Dexedrine), phenmetrazine (Preludin, Filon), phentermine (Duromine), chlorphentermine (Lucofen), diethyl propion (Tenuate, Apisate), and fenfluramine (Ponderax). Dangers of addiction, abuse, and numerous side-effects have curtailed their use. Details of their mode of action and their metabolism are described in the Milan Symposium (Costa \& Garattini, I970.) Currently, phentermine, diethyl propion and fenfluramine are used and each has certain advantages and disadvantages (Munro, 1973). A benzoyl-oxy-derivative of fenfuramine, S992, is another interesting appetite suppressor (Pawan, Payne \& Sheldrick, 197I).

Mazindol (Teronac). This isoindole compound has recently been introduced as a non-amphetamine appetite suppressant which is claimed to differ from the amphetamines in its site and mechanism of action. (DeFelice, Bronstein \& Cohen, I969; Hadler, 1972; Götestam \& Gunne, 1972). Clinical trials are being carried out to assess its usefulness.

Biguanides. These oral hypoglycaemic agents, phenethyl biguanide (Phenformin) and dimethyl biguanide (Metformin), have been found useful in treating obese diabetics. It has been suggested that they may help to reduce appetite and food intake (Pedersen, 1965; Roginsky \& Barnett, 1966; Danowski, r967; Clarke \& Duncan, I968; Stowers \& Bewsher, 1969; Lawson, Roscoe, Strong, Gibson \& Peattie, 1970; Malcolm, Mace, Outar \& Pawan, 1972).

Miscellaneous Drugs. Glucagon has been found to reduce appetite and food intake when injected (Penick \& Hinkle, I96r), and there is some evidence that cigarette smoking may reduce appetite (Batterman, 1955; Brozek \& Keys, I957; Fletcher \& Doll, 1969; Comstock \& Stone, 1972). The fat-mobilizing substance in fasting rat urine has been separated into a fraction, FMS IA, which has appetite-depressing properties (Stevenson, Box \& Szlavko, 1964; Mukaida \& Lichton, I97I). In some animal species, injection of agonists of the $\beta$-adrenergic receptors of the lateral hypothalamus, e.g. L-epinephrine and salbutamol, reduces appetite, as do injections of $\alpha$-antagonists, e.g. phentolamine, into the ventro-medial hypothalamus (Liebowitz, I 970), and intra-hypothalamic injection of prostaglandin Er (Baile, Simpson, Bean, McLaughlin \& Jacobs, I973). Several other substances have been shown to depress appetite and food intake. It should be remembered that agents which produce nausea, toxins, especially hepatotoxins, (Drill, 1952), pyrogens (Beamer \& Thomas, 1954), and other deleterious substances may reduce appetite and food intake.

\section{REFERENCES}

Anand, B. K. (1961). Physiol. Rev. 4r, 677.

Anand, B. K. Chhina, G. S. \& Singh, B. (1962). Science, N. Y. r38, 597.

Anand, B. K. \& Pillai, R. V. (1967). F. Physiol., Lond. 192, 63.

Baile, C. A. (1971). F. Dairy Sci. 54, 564. 
Baile, C. A., Simpson, C. W., Bean, S. M., McLaughlin, C. L. \& Jacobs, H. L.(x973.) Physiol. Behav. ro, 1077 .

Baile, C. A. \& Forbes, J. M. (1974). Physiol. Rev. 54, 160.

Bassett, J. M. (1963). F. Endocr. 26, 539 .

Batterman, R. L. (1955). In The Biologic Effects of Tobacco p. I4० [E. L. Wynder, editor]. Boston, Mass.: Little \& Brown.

Beamer, W. D. \& Thomas, J. E. (1954). Gastroenterology 27, 347.

Beazell, J. M. \& Ivy, A. C. (1940). Q. Fl Stud. Alcohol r, 45.

Becker, E. J. (1958). F. Nutr. 66, 237.

Bell, F. R. (197I). Proc. Nutr. Soc, 30, I03.

Benady, D. R. (1970). Y. ment. Sci. r77,68r.

Braude, R. (1948) Nature, Lond. I6r, 856.

Brobeck, J. R. (1948). Yale F. Biol. Med. 20, 545.

Brozek, J. \& Keys, A. (1957). Science, N.Y. 125, 1203.

Bruch, H. (I974). Eating Disorders Part I, p.3. London: Routledge \& Kegan Paul.

Cannon, W. B. \& Washburn, A. L. (19r2). Am. F. Physiol. 29, 44I.

Chakrabarty, A. S., Pillai, R. V., Anand, B. K. \& Singh, B. (1967). Brain Res. 6, 56r.

Clarke, B. F. \& Duncan, L. J. P. (1968). Lancet i, 123.

Comstock, G. W. \& Stone, R. W. (1972). Archs envir. Hlth 24, 27 I.

Costa, E. \& Garattini, S. (editors) (1970). Amphetamines \& Related Compounds. New York: Raven Press:

Danowski, T. S. (1967). Metabolism 16, 9.

DeFelice, E. A., Bronstein, S. \& Cohen, A. (1969). Curr, ther, Res. I1, 256.

Dinusson, W. E., Andrews, F. N. \& Beeson, W. M. (1950). F. Anim. Sci. 9, 321.

Drash, A., Elliott, J., Langs, H., Lavenstein, A. F. \& Cooke, R. E. (1966). Clin. Pharmac. Ther. 7, 340.

Dreiling, D. A., Richardson, A. \& Fradkin, N. F. (1952). Gastroenterology 20, 636.

Drill, V. A. (1952). Pharmac. Rev. 4, 1.

Fletcher, C. M. \& Doll, R. (I969). Br. F. prev. soc. Med. 23, 145.

Forbes, J. M. \& Rook, J. A. F. (1970). F. Physial., Lond. 207, 79P.

Goslings, J., Hymans, W., Van Limpt, P. M. \& Van Gilse, H. A. (1950). Br. med. f. ii, Iorg.

Götestam, K. G. \& Gunne, L. (1972). Br. I. Addict. Alcohol 67, 39.

Hadler, A. J. (1972). F. clin. Pharmac. \& $\%$. New Drugs 12, 453 .

Hench, P. S., Kendall, E. C., Slocumb, C. H. \& Polley, H. F. (r950). Archs intern. Med. 85, 545.

Hervey, G. R. (1971). Proc. Nutr. Soc. 30, rog.

Hervey, G. R. \& Hervey, E. (1964). 7. Endocr. 30, vii.

Higa, J., Micelli, I. \& Astolf, E. (Ig69). Prensa méd. argent. 56, 1129.

Hollister, L. E. (I 957). New Engl. F. Med, 257, 170.

Jacobs, H. L. \& Sharma, K. N. (1969). Ann. N.Y. Acad. Sci. 157, 1084.

Jukes, T. H. \& Williams, W. L. (1953). Pharmac. Rev. 5, 38 r.

Kekwick, A. \& Pawan, G. L. S. (1965). F. Endocr. 31, 265.

Kennedy, G. C. (1953). Proc. R. Soc. B 140, $57^{8}$.

Kennedy, G. C. \& Mitra, J. (1963). F. Physiol., Lond. 166, 395.

Lavenstein, A. F., Dacaney, E. P., Lasagna, L. \& Van Metre, T. E. (I962). F. Am. med. Ass. I80, 912.

Lawson, A. A. H., Roscoe, P., Strong, J. A., Gibson, A. \& Peattie, P. (1970). Lancet ii, 437.

Liebowitz, S. F. (1970). Proc, natn. Acad. Sci. U.S.A. 67, 1063.

Liebowitz, S. F. (r971). Proc. natn. Acad. Sci. U.S.A. 68, 332.

MacKay, E. M., Callaway, J. W. \& Barnes, R. H. (1940). F. Nutr. 20, 59.

Mainguet, P. (1972). Practitioner 208, 797.

Malcolm, A. D., Mace, P. M., Outar, K. P. \& Pawan, G. L. S. (1972). Proc. Nutr. Soc. 3I, 12 A.

Mayer, J. (1953). Physiol. Rev. 33, 472.

Mayer, J. (1955a). Nutr. Abstr. Rev. 25, 597.

Mayer, J. (1955b). Nutr. Abstr. Rev. 25, 871.

Meites, J. (1949). Am. F. Physiol. I59, 28 I.

Mellinkoff, S. M. (1957). A. Rev. Physiol. 19, 175.

Morgane, P. J. \& Jacobs, H. L. (1969). Wld Rev. Nutr. Diet. ro, 100.

Mukaida, C. S. \& Lichton, I. J. (1971). F. Nutr. Ior, 767.

Munro, J. F. (1973). In Symposium on Anorexia Nervosa and Obesity p. Ioo [R. F. Robertson, editor]. Edinburgh: Royal College of Physicians.

Nahum, L. H. \& Himwich, H. E. (1932). Am. F. med. Sci. 183, 608.

Noble, R. E. (1969). F. Am. med. Ass. 209, 2054.

Novin, D., VanderWeele, D. A. \& Rezek, M. (1973). Science, N.Y. I81, 858.

Pawan, G. L. S., Payne, P. M. \& Sheldrick, E. C. (r97I). Proc. Nutr. Soc. 30, 8A.

Pedersen, J. (1965). Acta endocr., Copenh. 49, 479.

Penick, S. B. \& Hinkle, L. E. (196r). New Engl. F. Med. 264, 893 . 
Roginsky, M. S. \& Barnett, J. (I966). Am. F. clin. Nutr. 19, 223.

Sanzgiri, R. R., Mohamad, H. A. \& Raja, Z. (r970). F. postgrad. Med. 16, 12.

Settel, E. (1958). F. clin. exp. Psychopath. 8, 98.

Silbert, M. V. (1971). S. Afr. med. F. 45, 374.

Silverstone, J. T. (1973). Br. Y. hosp. Med. 10, 39.

Smith, M. H. (1966). F. comp. Physiol. Psychol. 6r, 398.

Smith, G. P. \& Epstein, A. N. (1969). Am. Y. Physiol. 217, 1083.

Spurlock, G. M. \& Clegg, M. T. (1962). Y. Anim. Sci. 2I, 494.

Stevenson, J. A. F., Box, B. M. \& Szlavko, A. J. (1964). Proc. Soc. exp. Biol. Med. 115, 424.

Stiel, J. N., Liddle, G. W. \& Lacy, W. W. (1970). Metabolism 19, 192.

Stowers, J. M. \& Bewsher, P. D. (1969). Post-grad. med. J. 45, 12. 